\title{
First report of cyanobacterial paralytic shellfish toxin biosynthesis genes and paralytic shellfish toxin production in Polish freshwater lakes
}

\author{
Henna Savela, ${ }^{1 *}$ Lisa Spoof, ${ }^{2}$ Niina Höysniemi, ${ }^{1}$ Markus Vehniäinen, ${ }^{1}$ Joanna Mankiewicz-Boczek, ${ }^{3}$ Tomasz Jurczak, ${ }^{4}$ \\ Mikolaj Kokociński, ${ }^{5} \mathrm{Jussi}^{\text {Meriluoto}}{ }^{2}$
}

\begin{abstract}
${ }^{1}$ Biotechnology, Department of Biochemistry, University of Turku, Tykistökatu 6A, 20520 Turku, Finland; ${ }^{2}$ Department of Biochemistry and Pharmacy, Faculty of Science and Engineering, Åbo Akademi University, Tykistökatu 6A, 20520 Turku, Finland; ${ }^{3}$ European Regional Centre of Ecohydrology of the Polish Academy of Sciences, Tylna 3, 90-364 Łódź, Poland; ${ }^{4}$ Department of Applied Ecology, Faculty of Biology and Environmental Protection, University of Łódź, Banacha 12/16, 90-237 Łódź, Poland; ${ }^{5}$ Department of Hydrobiology, Faculty of Biology, Adam Mickiewicz University, Umultowska 89, 61-614 Poznań, Poland

*Corresponding author. e-mail: henna.savela@utu.fi
\end{abstract}

\begin{abstract}
In central and southern Europe, Aphanizomenon spp., A. gracile Lemmermann in particular, have been associated with paralytic shellfish toxin (PST) production. In western Poland, A. gracile is very common, and Cylindrospermopsis raciborskii (Woloszyńska) Seenayya \& Subba Raju, another potentially PST-producing species, is often found as well. To date it is, however, unknown if the cyanobacterial populations in this area harbour the genetic capability to produce PSTs, and to what extent toxin biosynthesis occurs. The objective of this study was to survey the prevalence of potentially PST-producing cyanobacteria by measuring paralytic shellfish toxin biosynthesis gene $s x t B$ copy numbers, $s x t A$, $s x t G$ and $s x t S$ gene presence, and PST concentrations in Polish freshwater lakes. In total, 34 lakes in western Poland were sampled twice during summer 2010. The presence of PST biosynthesis genes $s x t A$, sxt $G$ and $s x t S$ was determined using conventional qualitative PCR. Quantitative PCR (qPCR) was used to measure sxtB copy numbers, and the samples were analysed for PSTs using ion-pair high performance liquid chromatography with post-column oxidation and fluorescence detection (HPLC-FLD). Cyanobacteria carrying the $s x t B$ gene were present in $23.5 \%$ of all samples $(\mathrm{n}=16)$ and in 14 lakes of the studied 34 . Gene copy numbers ranged from $8.2 \times 10^{4}$ to $5.1 \times 10^{7} s x t B$ copies $\mathrm{L}^{-1}$ (mean $3.8 \times 10^{6}$ ). The median was $4.5 \times 10^{5} s x t B$ gene copies $\mathrm{L}^{-1}$ and the majority of results clustered at the lower end of the $s x t B$ qPCR linear range. In 12 out of the 16 samples positive for $s x t B$ the gene co-occurred with the other three targeted PST biosynthesis genes $s x t A$, sxt $G$ and $s x t S$. However, five additional samples lacked one or two of the targeted four genes. Thirteen samples contained PSTs, of which 12 samples at levels $<0.072 \mu \mathrm{g} \mathrm{L}^{-1}$, i.e., close to or below the quantitative detection limit of the HPLC-FLD method $\left(0.01 \mu \mathrm{g} \mathrm{L}^{-1}\right)$. One sample contained $0.57 \mu \mathrm{g} \mathrm{L}^{-1}$ saxitoxin, co-occurring with all four sxt genes studied. No correlation between PST and sxt gene occurrence or copy numbers was observed. A. gracile and C. raciborskii occurred in $92 \%$ and $50 \%$ of samples, respectively, containing PSTs, sxt genes or both. In conclusion, the results confirm that potential PST producers constitute an established subpopulation of cyanobacteria in Polish freshwater lakes. However, none of the sxt genes targeted in this study could serve as a reliable marker for active PST biosynthesis.
\end{abstract}

Key words: Saxitoxin; paralytic shellfish toxins; cyanobacteria; lakes; quantitative PCR; PCR.

Received: 30 September 2016. Accepted: 30 January 2017.

\section{INTRODUCTION}

Saxitoxins or paralytic shellfish toxins (PSTs) are a group of potent alkaloid neurotoxins produced by a number of freshwater cyanobacterial species, as well as by certain marine dinoflagellates. Paralytic shellfish toxins accumulate in the food chain, and consumption of toxincontaminated seafood can lead to potentially severe poisoning. Health risks are also associated with the use of water sources harbouring PST-producing cyanobacteria for e.g. drinking water production or recreation. In Europe, PSTs have been detected widely in freshwater lakes, rivers and reservoirs; in Czech Republic (Jančula et al., 2014) and Spain PST production has been associated with blooms of Aphanizomenon spp. (Wörmer et al., 2011). In
Finland (Rapala et al., 2005; Savela et al., 2015) and Denmark (Kaas and Henriksen, 2000) Dolichospermum lemmermannii (Richter) P. Wacklin, L. Hoffmann \& J. Komárek (formerly Anabaena lemmermannii, Wacklin et al., 2009), a species closely related to Aphanizomenon gracile Lemmermann (Cirés and Ballot, 2016), has been implicated as the most likely PST-producing species. Moreover, biosynthesis of PSTs has been confirmed in numerous strains of $A$. gracile from Germany, Portugal and France (Pereira et al., 2004; Ballot et al., 2010; Ledreux et al., 2010; Casero et al., 2014; Cires et al., 2014) and Cuspidothrix issatschenkoi (Usachev) P. Rajaniemi, Komárek, R. Willame, P. Hrouzek, K. Kastovská, L. Hoffmann \& K. Sivonen (formerly Aphanizomenon issatschenkoi, Rajaniemi et al., 2005) from Portugal 
(Pereira et al., 2000; Li et al., 2003). Other PST-producing cyanobacteria encountered elsewhere in the world include Cylindrospermopsis raciborskii (Woloszyńska) Seenayya \& Subba Raju (Lagos et al., 1999), Dolichospermum circinale (Rabenhorst ex Bornet \& Flahault) P. Wacklin, L. Hoffmann \& J. Komárek (formerly Anabaena circinalis, Wacklin et al., 2009) and Plectonema wollei Farlow ex Gomont (Carmichael et al., 1997), Raphidiopsis brookii Hill (Yunes et al., 2009), Scytonema sp. (Smith et al., 2011), Geitlerinema spp., Phormidium uncinatum Gomont ex Gomont, and Cylindrospermum stagnale Bornet \& Flahault (Borges et al., 2015). Of the above mentioned species, C. raciborskii is commonly found also in European lakes, including Poland (Kokociński and Soininen, 2012), but has not been associated with PST production in Europe to date.

PSTs affect vertebrate nerve function by reversibly blocking voltage-gated ion channels, primarily $\mathrm{Na}^{+}$ (Llewellyn, 2006), but also $\mathrm{K}^{+}$and $\mathrm{Ca}^{2+}$ channels are affected (Kao, 1986, Wang et al., 2003, Su et al., 2004). Ion channel blockage leads to inhibition of neuronal signal transduction, the extent of which is directly dependent on PST concentration. Disruption of neuronal signals leads to symptoms ranging from slight numbness and tingling of extremities to full respiratory arrest and death in extreme cases (Llewellyn, 2006). The effectivity of ion channel blockage depends on the structural characteristics of each given PST variant, 57 of which have been identified (Wiese et al., 2010). The biosynthesis of all PSTs is directed by a suite of biosynthetic genes ( $s x t$ ), first described in C. raciborskii strain T3 (Kellmann et al., 2008). Since then, toxinspecific molecular genetic analysis has been employed in the study of PST-producing cyanobacteria in culture and in the field. Several studies on European cyanobacteria have been carried out on strains isolated from freshwater lakes and reservoirs, and many have targeted the PST biosynthesis gene $s x t A$ showing that while all PST-producing strains do carry the gene, it can also be found in Anabaena, Anabaenopsis and Aphanizomenon strains which appear to lack the ability to produce the toxins (Ballot et al., 2010; Ledreux et al., 2010; Cires et al., 2014). Other sxt genes, including $s x t G, s x t B, s x t I$ and $s x t X$, have been studied to a lesser extent (Casero et al., 2014, Gkelis and Zaoutsos, 2014, Savela et al., 2015). Only a few studies have investigated the co-occurrence of sxt genes and PSTs in environmental samples in Europe (Gkelis and Zaoutsos, 2014; Savela et al., 2015) or elsewhere in the world (Al-Tebrineh et al., 2012; Bowling et al., 2013).

Cyanobacterial toxins are common in western Polish lakes; cylindrospermopsin, produced primarily by $A$. gracile, is found at concentrations exceeding WHO recommendations (Kokociński et al., 2013). Hepatotoxic microcystins are another common cyanotoxin group in Polish lakes (Mankiewicz-Boczek et al., 2006). However, neither the prevalence of potentially PST-producing cyanobacteria, indicated by the presence of biosynthesis genes ( $s x t)$, nor PSTs in Polish lakes has been previously studied (Kobos et al., 2013). In this study, qualitative PCR methods targeting the $s x t A$ and $s x t G$ genes and a quantitative method for the detection of $s x t B$, which have been previously employed in the analysis of lakes and brackish coastal waters in Åland Islands, Finland (Savela et al., 2015) were applied to investigate freshwater lakes in western Poland. Targeting previously studied genes allowed comparisons to existing data. To assess the potential benefit of adding a new gene target to the analysis, primers for the detection of the PST biosynthesis gene sxt $S$ were designed and used to complement existing methods. This study reports the first analysis of Polish freshwater lakes for the prevalence of selected cyanobacterial paralytic shellfish toxin biosynthesis genes as well as PST prevalence and concentrations.

\section{METHODS}

\section{Study site and sampling}

Sampling was carried out in randomly selected freshwater lakes $(n=34)$ in Western Poland twice during summer 2010; first between June $6^{\text {th }}$ and July $23^{\text {rd }}$ (Tab. 1 ) and again between August $20^{\text {th }}$ and October $1^{\text {st }}$ (Tab. 2). The limnological characteristics and geographical locations of the lakes as well as the sampling procedure have been described in detail by Kokociński et al. (2013). Briefly, 3 to 4 subsamples were taken at $1 \mathrm{~m}$ vertical intervals using a $0.5 \mathrm{~m}$ Limnos sampler starting at the depth of $1 \mathrm{~m}$. One litre of the pooled subsamples from each location was transported to the laboratory and used for phytoplankton identification and biomass calculations (as described in Kokociński et al., 2013) and molecular and toxin analyses.

\section{Sample preparation for molecular analyses}

Aliquots $(20 \mathrm{~mL})$ of the $1 \mathrm{~L}$ subsample were filtered onto $25 \mathrm{~mm}$ diameter Whatman $\mathrm{GF} / \mathrm{C}$ filters and stored frozen $\left(-20^{\circ} \mathrm{C}\right)$. Addition of exogenous amplification control and heat treatment $\left(80^{\circ} \mathrm{C}, 10 \mathrm{~min}\right)$ in sterile deionized water $(\mathrm{V}=1.5 \mathrm{~mL})$ water to lyse the cyanobacteria were carried out as described previously (Savela et al., 2014). The resulting lysate was stored frozen $\left(-20^{\circ} \mathrm{C}\right)$ until further analysis. Spectrophotometric analysis of DNA quantity and quality was not applicable to this sample type.

\section{Qualitative analysis of $s x t A, \operatorname{sxt} G$ and $s x t S$}

Sample lysates were analysed for the presence of PST biosynthesis genes $s x t A, s x t G$ and $s x t S$ using primers listed in Tab. 3. Successful amplification resulted in 648 bp, 519 bp and 382 bp PCR products, respectively. The specificity 
of $s x t A$ and $\operatorname{sxt} G$ primers has been validated previously (Savela et al., 2015). For this study, the in silico specificity of sxtS primers was confirmed by running a query against the GenBank nr database (as available in February 2011) using blastn 2.2.29+ for highly similar sequences (Altschul et al., 1997) and optimized for short input sequences. The sxtS target is located at bases 130-511 of the D. circinale AWQC131C (DQ787201) and the Aphanizomenon sp. NH-5 (EU603710) sxtS gene and bases 216597 of the C. raciborskii T3 (DQ787200) sxtS gene. The in vitro specificity was confirmed by analysing PST-producing and non-producing cyanobacterial strains following the same procedures as for $s x t A$ and $s x t G$ (Savela et $a l ., 2015)$. For environmental sample analysis, $s x t A, s x t G$ and $s x t S$-specific PCR reactions (total volume $20 \mu \mathrm{L}$ ) contained 1X Phire Reaction buffer and $0.4 \mu \mathrm{L}$ Phire II HotStart DNA polymerase (Thermo Scientific), $0.2 \mathrm{mM}$ dNTPs (Bioline), $0.5 \mu \mathrm{M}$ appropriate forward and reverse primers and $4 \mu \mathrm{L}$ sample lysate. One ng of $D$. circinale CS-537/13 genomic DNA was used as the positive control. Thermal cycling was performed using a Bio-Rad C1000 Touch cycler: initial denaturation at $98^{\circ} \mathrm{C}$ for $30 \mathrm{~s}$, then 35 cycles of $98^{\circ} \mathrm{C} 5 \mathrm{~s}, 62^{\circ} \mathrm{C} 5 \mathrm{~s}$ and $72^{\circ} \mathrm{C} 10 \mathrm{~s}$, final extension at $72^{\circ} \mathrm{C}$ for $1 \mathrm{~min}$ (Savela et al., 2015). Reaction outcome was determined on $1 \% \mathrm{w} / \mathrm{v}$ agarose gels stained with $1 X$ (final conc.) SYBR $®$ Safe dye (Thermo Fisher Scientific). UV illumination and gel imaging was carried out using a Bio-Rad GelDoc XR system.

Tab. 1. The prevalence of $s x t A, s x t G, s x t S$, potentially PST-producing cyanobacterial species, the quantity of $s x t B$ gene copies and the concentration and identity of PSTs in western Polish lakes in June-July of 2010.

\begin{tabular}{|c|c|c|c|c|c|c|c|c|c|}
\hline Lake & $\begin{array}{c}\operatorname{sxtB} \\
\left(\operatorname{copies} \mathrm{L}^{-1}\right)\end{array}$ & $\begin{array}{l}\text { sxtA } \\
(+/-)\end{array}$ & $\begin{array}{l}\operatorname{sxtG} \\
(+/-)\end{array}$ & $\begin{array}{l}\text { sxtS } \\
(+/-)\end{array}$ & $\begin{array}{c}\text { PSTs } \\
\left(\mu \mathrm{g} \mathrm{L}^{-1}\right)\end{array}$ & $\begin{array}{c}\text { A. gracile } \\
(+/-)\end{array}$ & $\begin{array}{c}\text { C. issatschenkoi } \\
(+/-)\end{array}$ & $\begin{array}{c}\text { A. flos-aquae } \\
(+/-)\end{array}$ & $\begin{array}{c}\text { C. raciborski } \\
(+/-)\end{array}$ \\
\hline Biezdruchowo & - & - & - & - & - & + & - & - & - \\
\hline Biskupieckie & - & - & - & - & - & - & - & - & - \\
\hline Biskupińskie & - & - & - & - & - & + & - & - & + \\
\hline Bnińskie & - & - & - & - & - & + & - & - & + \\
\hline Boczowskie & - & - & - & - & 0.043 (STX) & + & - & - & + \\
\hline Busko & - & - & - & - & - & + & - & + & - \\
\hline Buszewskie & $4.98 \times 10^{5}$ & + & + & + & - & + & - & - & + \\
\hline Bytyńskie & - & - & - & - & - & + & - & - & + \\
\hline Długie & - & - & - & - & - & - & - & - & - \\
\hline Głębokie & - & - & - & - & - & - & - & - & - \\
\hline Grylewskie & - & - & - & - & - & + & - & - & + \\
\hline Ilno & - & - & - & - & - & + & - & + & - \\
\hline Jelonek & - & - & - & - & - & + & + & - & + \\
\hline Kierskie & - & - & - & - & trace $(\mathrm{STX})$ & + & - & - & - \\
\hline Kierskie Małe & $2.53 \times 10^{6}$ & + & + & + & trace (STX) & + & + & - & - \\
\hline Kowalskie & - & - & - & - & - & + & + & - & - \\
\hline Kruchowskie & - & - & - & - & - & - & - & - & - \\
\hline Kursko & - & - & - & - & - & + & + & + & + \\
\hline Lednica & - & - & - & - & - & - & - & - & - \\
\hline Lubosińskie & - & + & + & - & - & + & - & - & - \\
\hline Lusowskie & - & - & - & - & - & - & - & - & - \\
\hline Mogileńskie & $8.20 \times 10^{4}$ & - & + & - & trace (dcSTX) & + & + & - & - \\
\hline Niepruszewskie & - & - & - & - & - & - & - & - & - \\
\hline Niesłysz & - & - & - & - & - & - & - & - & - \\
\hline Pniewskie & - & - & - & - & - & + & - & - & - \\
\hline Sarbsko & $4.68 \times 10^{5}$ & + & + & + & 0.57 (STX) & + & + & - & - \\
\hline Strykowskie & - & - & - & - & - & + & - & - & - \\
\hline Strzyżewskie & $1.29 \times 10^{5}$ & + & + & + & - & + & + & - & - \\
\hline Świętokrzyskie & - & - & - & - & - & + & - & - & + \\
\hline Szydłowskie & - & - & - & - & - & + & + & - & - \\
\hline Tomickie & - & - & - & - & - & + & - & - & + \\
\hline Witobelskie & - & - & - & - & - & + & - & - & - \\
\hline Żabiniec & - & - & - & - & - & - & - & - & - \\
\hline Zbąszyńskie & - & - & - & - & - & + & + & + & - \\
\hline
\end{tabular}




\section{Quantitative analysis of $\operatorname{sxtB}$ copy numbers}

The quantitative PCR (qPCR) method used to detect and measure $s x t B$ copy numbers in cyanobacteria, and the method used to assess possible inhibition in environmental sample lysates have been described previously in detail by Savela et al. $(2014,2015)$.

Primer and probe sequences are listed in Tab. 3. Briefly, the labelling of the $s x t B$ detection probe with an intrinsically fluorescent terbium(III) chelate $\left(\left\{2,2,2^{\prime \prime}\right.\right.$, $2^{\prime \prime \prime}-\left\{\left\{6,6^{\prime}-\left\{4^{\prime \prime}\right.\right.\right.$-[2-(4-Isothiocyanatophenyl)ethyl]-pyratzole-1" ,3"'-diyl $\}$ bis(pyridine)-2,2'-diyl \} bis(methylenenitrilo)\}-tetrakis(acetato)\} Tb(III)), University of Turku, Turku, Finland) was carried out as described by Nurmi et al. (2002). The $20 \mu \mathrm{L}$ qPCR reactions contained $0.2 \mathrm{U}$ DyNAzyme II HotStart polymerase, 1X DyNAzyme II HS buffer, $0.2 \mathrm{mM}$ dNTPs (Finnzymes, Espoo, Finland), $0.4 \mathrm{mM}$ both primers, $24 \mathrm{nM}$ sxtB_Q quencher probe, 3 nM labelled sxtB_P detection probe and $4 \mu \mathrm{L}$ template; standard or sample lysate. Quantification standards were produced from $D$. circinale CS-537/13 genomic DNA, quantified, purified and diluted as described previously (Savela et al., 2015). Thermal cycling [MJ Research (St. Bruno, Canada) PTC-200 Thermal Cycler or Bio-Rad (Hercules, CA, USA) C1000 Touch Thermal Cycler] was performed as follows: initial denaturation, $95^{\circ} \mathrm{C} 5 \mathrm{~min}$, then 40 cycles of $95^{\circ} \mathrm{C} 30 \mathrm{~s}, 62^{\circ} \mathrm{C} 1 \mathrm{~min}$. Every second cycle, from cycle 8 to cycle 40 , after annealing and ex-

Tab. 2. The prevalence of $s x t A, s x t G, s x t S$, potentially PST-producing cyanobacterial species, the quantity of $s x t B$ gene copies and the concentration and identity of PSTs in western Polish lakes in August-October of 2010.

\begin{tabular}{|c|c|c|c|c|c|c|c|c|c|c|}
\hline Lake & $\begin{array}{c}\text { sxtB } \\
\left(\text { copies } \mathrm{L}^{-1}\right)\end{array}$ & $\begin{array}{l}\operatorname{sxt} A \\
(+/-)\end{array}$ & $\begin{array}{l}\operatorname{sxtG} \\
(+/-)\end{array}$ & $\begin{array}{l}\text { sxts } \\
(+/-)\end{array}$ & $\begin{array}{c}\text { PSTs } \\
\left(\mu \mathrm{L} \mathrm{L}^{-1}\right)\end{array}$ & $\begin{array}{l}\text { A. gracile } \\
(+/-)\end{array}$ & $\begin{array}{c}\text { C. issatschenkoi } \\
(+/-)\end{array}$ & $\begin{array}{c}\text { C. ovalisporum } \\
(+/-)\end{array}$ & $\begin{array}{l}\text { A. flos-aquae } \\
(+/-)\end{array}$ & $\begin{array}{c}\text { C. raciborskii } \\
(+/-)\end{array}$ \\
\hline Biezdruchowo & - & - & - & - & - & + & - & - & - & - \\
\hline Biskupieckie & - & - & - & - & - & - & 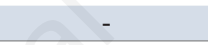 & - & - & - \\
\hline Biskupińskie & - & - & - & - & trace (STX) & + & - & - & - & + \\
\hline Bnińskie & - & + & + & + & - & + & 10 & - & - & + \\
\hline Boczowskie & - & - & - & - & - & + & (2) & - & - & + \\
\hline Busko & $4.31 \times 10^{5}$ & + & + & + & trace $(\mathrm{STX})$ & - & - & - & - & - \\
\hline Buszewskie & - & - & - & $-\mathrm{t}$ & race $(\mathrm{dcSTX})$ & + & - & - & - & + \\
\hline Bytyńskie & - & - & - & - & - & + & - & - & - & + \\
\hline Długie & - & - & - & - & trace (STX) & - & - & - & - & - \\
\hline Głębokie & - & - & - & - & - & - & - & - & - & - \\
\hline Grylewskie & - & - & - & - & - & + & - & - & - & + \\
\hline Ilno & $5.10 \times 10^{7}$ & + & + & + & 0.072 (STX) & + & + & - & + & - \\
\hline Jelonek & - & - & - & - & - & + & - & - & + & + \\
\hline Kierskie & - & - & - & - & - & + & + & - & + & - \\
\hline Kierskie Małe & - & - & - & - & - & + & + & - & - & + \\
\hline Kowalskie & $1.28 \times 10^{5}$ & + & + & + & - & + & + & - & - & - \\
\hline Kruchowskie & $8.37 \times 10^{5}$ & + & + & + & trace $(\mathrm{STX})$ & + & - & - & - & + \\
\hline Kursko & $1.32 \times 10^{5}$ & + & + & + & - & + & + & - & + & + \\
\hline Lednica & - & - & - & - & - & - & - & - & - & - \\
\hline Lubosińskie & $3.97 \times 10^{5}$ & + & + & - & - & + & - & - & - & + \\
\hline Lusowskie & - & - & - & - & - & - & - & - & - & - \\
\hline Mogileńskie & $2.50 \times 10^{5}$ & + & + & + & - & + & + & - & - & + \\
\hline Niepruszewskie & - & - & - & - & - & - & - & - & - & - \\
\hline Niesłysz & - & - & - & - & - & + & - & - & + & - \\
\hline Pniewskie & - & - & - & -0 & $.069(\mathrm{dcSTX})$ & + & - & - & - & + \\
\hline Sarbsko & $9.85 \times 10^{5}$ & + & + & + & - & + & + & + & - & - \\
\hline Strykowskie & - & - & - & - & - & + & - & - & - & + \\
\hline Strzyżewskie & - & - & - & - & - & + & + & - & + & - \\
\hline Świętokrzyskie & - & - & - & - & - & - & - & - & + & + \\
\hline Szydłowskie & $3.96 \times 10^{5}$ & + & + & + & - & + & + & - & - & - \\
\hline Tomickie & $5.49 \times 10^{5}$ & + & + & + & - & + & - & + & + & + \\
\hline Witobelskie & - & - & - & - & - & + & - & - & - & + \\
\hline Żabiniec & - & - & - & - & - & + & + & - & - & + \\
\hline Zbąszyńskie & $1.14 \times 10^{5}$ & + & + & - & - & + & - & - & + & + \\
\hline
\end{tabular}


tension the temperature was lowered to $35^{\circ} \mathrm{C}$ for $15 \mathrm{~s}$, during which $\mathrm{Tb}$ fluorescence was measured using the standard TRF-Tb protocol on a Victor X4 2030 Multilabel Reader (PerkinElmer, Waltham, MA, USA).

\section{Extraction and analysis of PSTs}

Extraction of PSTs from water sample aliquots preserved on filters and the analysis of the resulting extracts using ion-pair high-performance liquid chromatography with post-column oxidation and fluorescence detection (HPLC-FLD) was carried out as described previously (Savela et al., 2015). Certified reference materials included C-toxins (C1-2), gonyautoxins (GTX1-4, GTX23, GTX5), decarbamoyl gonyautoxins (dcGTX2-3), saxitoxin (STX), decarbamoyl saxitoxin (dcSTX) and neosaxitoxin (NeoSTX) (NRC-IMB, Halifax, Canada).

\section{Data analysis}

Raw fluorescence measurement data from the qPCR experiments was analysed in Microsoft Excel 2010. Amplification curves were generated by plotting well-specific signal-to-background ratios against their respective PCR cycles. Background was determined for each individual reaction separately; the average signal of the first two measurements was used. $\mathrm{C}_{\mathrm{q}}$-values were determined visually, and values deviating from the other replicates by more than one cycle were not considered in the final analysis. Statistical analysis was carried out using R Statistical package version 3.2.0 (R Core Team, 2015).

\section{RESULTS}

\section{sxt genes}

Specificities of the $s x t A$ and $s x t G$ PCR methods as well as the properties of the $s x t B$ qPCR assay have been described previously by Savela et al. (2015). For this study, an additional primer pair targeted at the paralytic shellfish toxin biosynthetic gene sxtS was applied to analysis of environmental samples. In silico analysis revealed no significant non-target hits, and no amplification was observed in cyanobacterial strains incapable of PST production (Tab. 4, Supplementary Figure S1). The $s x t B$ gene was amplified in $14(41.1 \%)$ out of the 34 lakes investigated in this study. In total, $23.5 \%$ of all samples contained the $s x t B$ gene, detection frequency increasing towards the end of summer, from $18 \%$ in JuneJuly (Tab. 1) to $29 \%$ in August-October (Tab. 2). Significant inhibition in the amplification of the exogenous amplification control was not observed. For two of these lakes, Lake Mogileńskie and Lake Sarbsko, the $s x t B$ gene was found in samples taken both in June-July and August--October. Overall, sxtB copy numbers were low; in June-July the average was $7.4 \times 10^{5}$ copies $\mathrm{L}^{-1}$ (median $\left.4.7 \times 10^{5}\right)$. In August-October the average was $5.1 \times 10^{6}$ copies $\mathrm{L}^{-1}$, but the median only $4.1 \times 10^{5}$. Only one relatively high $s x t B$ copy number was measured in a sample collected at Lake Ilno in August 2010, 5.1 $\times 10^{7}$ copies $\mathrm{L}^{-1}$. The presence of sxtA, sxt $G$ and sxt $S$ genes was confirmed in $75 \%(\mathrm{n}=12)$ of the $s x t B$-positive samples. One to two target genes were absent from five samples. In four samples, either the gene $s x t B$ or $s x t S$ was absent, once both genes $s x t A$ and $s x t S$ were not detected (Tabs. 1 and 2).

\section{Paralytic shellfish toxins}

PSTs were detected in a total of 13 samples. One sample, collected at Lake Sarbsko in July 2010 contained 0.57 $\mu \mathrm{g} \mathrm{L}^{-1}$ saxitoxin. In three of the PST-positive samples concentrations between 0.043-0.072 $\mu \mathrm{g} \mathrm{L}^{-1}$ were measured, and the majority $(n=9)$ contained trace amounts of PSTs, the concentrations not exceeding the quantitative detection limit of the HPLC-FLD method $\left(0.01 \mu \mathrm{g} \mathrm{L}{ }^{-1}\right.$, Savela et al., 2015). Only saxitoxin and decarbamoylsaxitoxin were present in the samples, other variants were not detected. PSTs or sxt genes were observed in 18 samples of

Tab. 3. Primers and probes for conventional qualitative PCR and qPCR used in this study.

\begin{tabular}{lll} 
Gene & Name & Sequence $\left(\mathbf{5}^{\prime}-\mathbf{3}^{\prime}\right)$ \\
sxtA & sxtA855_F* & GACTCGGCTTGTTGCTTCCCC \\
& sxtA1480_R & GCCAAACTCGCAACAGGAGAAGG \\
sxtG & sxtG432_F* & AATGGCAGATCGCAACCGCTAT \\
& sxtG928_R & ACATTCAACCCTGCCCATTCACT \\
\hline sxtS & sxtS205_F & GGAGTATTGGCGGGTGACTATGA \\
& sxtS566_R & GGTGGCTACTTGGTATAACTCGCA \\
sxtB & sxtB_F2* & TGTTGTGCTTGCTGCTCTATCAG \\
& sxtB_R2* & CAGCGTTTCAGCGTAYCGAC \\
& sxtB_P detection probe & aminoC6-CAATCAAAGTTATGCTCCCTATACGA-Phos \\
& sxtB_Q quencher probe & GGGAGCATAACTTTGATTG-BHQ 1 \\
\hline
\end{tabular}

*Savela et al., 2015; ${ }^{\circ}$ this study. 
the total 68 . Only 6 of the 68 samples contained both PSTs and $s x t$ genes. No quantitative correlation between $s x t B$ copy numbers and PST concentrations was observed (Spearmans's $\rho=0.19, \mathrm{P}=0.11$ ).

\section{Identification of potentially PST-producing cyanobacteria}

Cyanobacterial populations in the studied lakes at the times of sampling were analysed for potentially PST-producing species (Tabs. 1 and 2). Particularly A. gracile was abundant, present in $75 \%$ of all samples, being as common in June-July as in August-October. The species was present in $83 \%$ and $94 \%$ of PST- and sxt-gene containing samples, respectively. C. raciborskii was also commonly observed, the overall prevalence increasing from $29 \%$ to $56 \%$ towards the end of summer. It was present in $42 \%$ and $44 \%$ of PST- and sxt-gene containing samples, respectively. Of other potentially PST-producing species, C. issatschenkoi was observed in $26 \%$ and $29 \%$ and Aphanizomenon flos-aquae Ralfs ex Bornet \& Flahault in $12 \%$ and $26 \%$ of all samples in June-July and August-October, respectively. Of these two, C. issatschenkoi was present in $50 \%$ and $56 \%$ of the PST- and sxt-gene containing samples. The corresponding percentages for $A$. flos-aquae were $8 \%$ and $22 \%$. C. ovalisporum was present in two samples (6\%) in August-October, one of which contained both PSTs and sxt genes.

\section{DISCUSSION}

In this study, potentially PST-producing cyanobacteria were for the first time indicated in Polish lakes on the basis of sxt gene detection. Additionally, active but lowlevel biosynthesis of PSTs was demonstrated by the presence of saxitoxin or decarbamoylsaxitoxin in 19\% of the 68 samples tested. The results are in line with other studies investigating central European freshwaters (Ballot $e t$ al., 2010; Ledreux et al., 2010, Jančula et al., 2014).

On average, the $s x t$ gene cluster includes 30 genes, the exact number as well as the composition and arrangement of genes within the cluster being genus-dependent (Mihali et al., 2009). The gene cluster includes so-called "core", or essential genes, without which PST biosynthesis cannot function (D'Agostino et al., 2014), and the majority of these are conserved among PST-producing cyanobacterial genera (Murray et al., 2011). Conserved core sxt genes include $s x t A, s x t B, \operatorname{sxt} G$ and $s x t S$ (Murray et al., 2011) which were targeted in this study. These four genes are responsible for the initiation of PST biosynthesis and formation of the three central heterocycles and the second

Tab. 4. Amplification of sxtS in in toxin-producing and non-toxic cyanobacteria.

\begin{tabular}{|c|c|c|c|}
\hline Species & Strain ${ }^{*}$ & $\operatorname{sxt} S^{\circ}$ & Toxins produced $^{\dagger}$ \\
\hline Dolichospermum circinale & CS-337/01 & + & PST \\
\hline Dolichospermum circinale & CS-537/13 & + & PST \\
\hline Dolichospermum circinale & CS-530/05 & - & nd \\
\hline Dolichospermum circinale & CS-533/12 & - & nd \\
\hline Anabaena cylindrica & PCC 73105 & - & nd \\
\hline Anabaena cylindrica & PCC 7938 & - & nd \\
\hline Dolichospermum lemmermannii var. minor & NIVA-CYA 83/1 & - & MCYST $\$$ \\
\hline Dolichospermum lemmermannii var. minor & NIVA-CYA 266/1 & - & MCYST $^{\S}$ \\
\hline Cylindrospermopsis raciborskii & CS-505 & - & $\mathrm{CYN}^{\wedge}$ \\
\hline Cylindrospermopsis raciborskii & CS-506 & - & $\mathrm{CYN}^{\$}$ \\
\hline Cylindrospermopsis raciborskii & CS-510 & - & nd \\
\hline Nodularia sphaerocarpa & PCC 7804 & - & L-HAr ${ }^{2}-\mathrm{NOD}^{* *}$ \\
\hline Nostoc sp. & PCC 6310 & - & nd \\
\hline Nostoc sp. & PCC 7422 & - & nd \\
\hline Microcystis aeruginosa & PCC 7806 & - & MCYST $^{\S}$ \\
\hline Microcystis aeruginosa & NIVA-CYA 140 & - & MCYST $^{\S}$ \\
\hline Microcystis aeruginosa & PCC 7005 & - & nd \\
\hline Planktothrix agardhii & NIVA-CYA 15 & - & MCYST $^{\S}$ \\
\hline Planktothrix agardhii & NIVA-CYA 299 & - & MCYST $\$$ \\
\hline Planktothrix agardhii & NIVA-CYA 12 & - & nd \\
\hline
\end{tabular}

"Strains were obtained from the Australian National Algae Culture Collection (ANACC, CS), Pasteur Culture Collection (PCC) and the Norwegian Institute for Water Research (NIVA). Culture conditions and DNA extraction have been previously described (Savela et al., 2015); ${ }^{\circ}$ this study; ${ }^{\#}$ data from

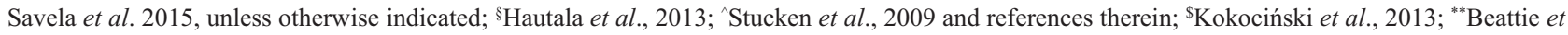
al., 2000; nd, not detected; MCYST, microcystins; CYN, cylindrospermopsin; L-HAr²-NOD, L-homoarginine²-nodularin. 
guanidino group present in all PST variants known to date, and are thus necessary for PST production (Kellmann et al., 2008, Mihali et al., 2009, Wiese et al., 2010). In the majority $(75 \%)$ of sxt-positive samples $(\mathrm{n}=18)$ all four genes were present. The presence of all four genes suggests a functional sxt gene cluster, although other genes are still needed to complete the biosynthesis route. Interestingly, in some samples $(\mathrm{n}=5)$ an apparent lack of one to two of the targeted sxt genes was observed. There are two possible explanations for this phenomenon. First, non-amplification might be caused by sequence dissimilarities between target and primers which could exist in natural cyanobacterial populations while being absent from the sxt gene sequences available at sequence databases. Both the $s x t A$ and $s x t G$ primer sequences are identical with their respective binding sites in Aphanizomenon sp. and $C$. raciborskii sequences, but nevertheless sxtA failed to amplify in one sample despite other sxt genes being present, indicating critical dissimilarities between the primers and the target. Both $s x t B$ and $s x t S$ forward primers share at most one known internal nucleotide mismatch with the corresponding sequences in the abovementioned species. An internal mismatch can affect reaction efficiency, but is not sufficient to abolish amplification, as shown by the robust amplification of sxtS in D. circinale, which shares an identical primer binding site, including the one mismatch, with Aphanizomenon sp. $\mathrm{NH}-5$. Second, mutations in a larger scale, including deletions and insertions within the $s x t$ gene cluster would result in a negative outcome in PCR analysis. Such mutations would also result in an inactive gene cluster and effectively a non-toxic cyanobacterial strain. Other cyanotoxin genes, most notably the microcystin biosynthesis genes are known to occasionally contain mutations rendering the biosynthesis pathway inactive (Christiansen et al., 2006; Noguchi et al., 2009; Ostermaier and Kurmayer, 2009). This suggests that similar mutations might be found also in PST-producing cyanobacteria. Indeed, previous studies have shown that the presence of sxt genes e.g. sxtA, does not always indicate detectable PST production in cyanobacteria; $s x t A$ has been detected in nonPST-producing Aphanizomenon, Anabaena and Anabaenopsis strains (Ballot et al., 2010; Casero et al., 2014). Similarly, in this study none of the analysed samples in which a partial set of $s x t$ genes was observed contained PSTs. However, the general lack of correlation between sxt gene presence and quantity and PST concentrations means that definitive conclusions on the presence of mutated sxt gene clusters cannot be drawn, and to confirm the hypothesis a suspected mutant strain would have to be isolated and the sxt genes characterized in detail.

An overall lack of correlation between sxt gene presence and copy number quantity and PST concentrations in the investigated lakes was apparent. Only a few surveys of environmental samples without prior strain isolation have been carried out, however, findings similar to this study have been obtained in Greece, where amplification of the sxtI gene was twice as common as PST detection (Gkelis and Zaoutsos, 2014) and during a three-year survey of lakes in Åland Islands in Finland using the same methods as in this study (Savela et al., 2015) with the exception of the new sxtS primers. The observed lack of correlation is not limited to Europe; in Australia, neither the presence of sxtA nor the gene's increasing copy numbers did indicate a detectable presence or growing concentrations of PSTs in the environment (Al-Tebrineh et al., 2012; Bowling et al., 2013). Comparisons of qPCR and HPLC-FLD data are complicated by the fact that qPCR can be extremely sensitive (Wittwer et al., 1997), whereas PSTs can be difficult to analyse in complex environmental sample extracts. For this reason, molecular analysis of PST biosynthesis genes have been proposed as an easier alternative for screening environmental samples for potential PST production. In this study, in addition to using HPLC-FLD, samples were originally analysed for PSTs using a hydrophilic interaction liquid chromatographytandem mass spectrometry (HILIC-MS/MS) method (Diener et al., 2007; Savela et al., 2015). Due to the very low PST concentrations, and similarly to previous work reported by Savela et al. (2015), only the HPLC-FLD method could be used to detect the toxins; its sensitivity was far superior compared to that of the HILIC-MS/MS method, which employed an ion-trap MS instrument. Notwithstanding methodological limitations, the findings from this and previous studies suggest regulation of PST production at the transcriptional and/or translational level, rather than toxin biosynthesis being a direct consequence of the biosynthetic capability encoded in the genome. Environmental factors including osmotic pressure, ionic stress and availability of organic nitrogen have been shown to affect sxt gene expression, PST production and export in Aphanizomenon spp., D. circinale and C. raciborskii (Dias et al., 2002; Pomati et al., 2004; Casero et al., 2014; Ongley et al., 2016), suggesting complex regulation mechanisms of toxin biosynthesis tied to the processes of primary metabolism. Therefore the simple approach of measuring sxt gene presence or copy number would not serve as a reliable indicator of PST production; measuring gene expression instead might predict active PST biosynthesis better.

Of the potentially PST-producing cyanobacteria, $A$. gracile was present in $83 \%$ and $94 \%$ of sxt gene- and/or PST-containing samples, respectively. The role of $A$. gracile in PST production is supported by its confirmed status as a PST-producing species in e.g. north-eastern Germany (Ballot et al., 2010). Previously, a positive correlation between $A$. gracile biomass and cylindrospermopsin, another cyanobacterial toxin, has already been 
shown (Kokociński et al., 2013). These observations suggest that $A$. gracile populations in western Polish lakes may contain both cylindrospermopsin- and PST-producing strains. However, the involvement of other Aphanizomenon species, which often co-occurred with $A$. gracile in the lakes included in this study, in PST production cannot be ruled out. Further study into the Aphanizomenon spp. described here would be required to definitely confirm the identity and possible role in PST production in Polish lakes. The second most common species to cooccur with sxt genes and/or PSTs was $C$. raciborskii. To date, the species has not been associated with PST production in European freshwaters, and conclusions of its possible role as a PST producer in western Polish lakes cannot be made without further investigation.

\section{CONCLUSIONS}

In this study, both the genetic capability for PST biosynthesis and active PST production in selected freshwater lakes in western Poland was demonstrated for the first time. The most likely potentially PST-producing species is A. gracile, however, further studies on isolated strains need to be conducted to confirm this hypothesis. The low $s x t B$ gene copy numbers and PST concentrations indicate that PST producers constituted a relatively minor subpopulation in the studied waterbodies. The non-amplification of certain sxt genes in the presence of others suggested the possible presence of inactive sxt gene clusters in the studied cyanobacterial populations. Since no significant correlation between genes sxtA, sxtB, sxt $G$ and $s x t S$, and measured PSTs was observed, it was concluded that analysis of $s x t$ genes indicates the presence of potentially PST-producing cyanobacteria, but is not suitable for predicting active PST biosynthesis in the studied Polish lakes.

\section{Acknowledgments}

This work was financially supported by the Finnish Funding Agency for Innovation (TEKES) grant 40013/10. The authors gratefully acknowledge the European Cooperation in Science and Technology, COST Action ES 1105 "CYANOCOST-Cyanobacterial blooms and toxins in water resources: Occurrence, impacts and management" for adding value to this study through networking and knowledge sharing with European experts and researchers in the field.

\section{References}

Al-Tebrineh J, Merrick C, Ryan D, Humpage A, Bowling L, Neilan BA, 2012. Community composition, toxigenicity, and environmental conditions during a cyanobacterial bloom occurring along 1,100 Kilometers of the Murray River. Appl. Environ. Microbiol. 78:263-272.

Altschul SF, Madden TL, Schaffer AA, Zhang J, Zhang Z, Miller W, Lipman DJ, 1997. Gapped BLAST and PSI-BLAST: a new generation of protein database search programs. Nucleic Acids Res. 25:3389-3402.

Ballot A, Fastner J, Wiedner C, 2010. Paralytic shellfish poisoning toxin-producing cyanobacterium Aphanizomenon gracile in northeast Germany. Appl. Environ. Microbiol. 76:1173-1180.

Beattie K, Kaya K, Codd G, 2000. The cyanobacterium Nodularia PCC 7804, of freshwater origin, produces [LHar2]nodularin. Phytochemistry 54:57-61.

Borges HLF, Branco LHZ, Martins MD, Lima CS, Barbosa PT, Lira GAST, Bittencourt-Oliveira, MC, Molica RJR, 2015. Cyanotoxin production and phylogeny of benthic cyanobacterial strains isolated from the northeast of Brazil. Harmful Algae 43:46-57.

Bowling LC, Merrick C, Swann J, Green D, Smith G, Neilan BA, 2013. Effects of hydrology and river management on the distribution, abundance and persistence of cyanobacterial blooms in the Murray River, Australia. Harmful Algae 30:27-36.

Carmichael WW, Evans WR, Yin QQ, Bell P, Moczydlowski E, 1997. Evidence for paralytic shellfish poisons in the freshwater cyanobacterium Lyngbya wollei (Farlow ex Gomont) comb. nov. Appl. Environ. Microbiol. 63:3104-3110.

Casero MC, Ballot A, Agha R, Quesada A, Cirés S, 2014. Characterization of saxitoxin production and release and phylogeny of sxt genes in paralytic shellfish poisoning toxin-producing Aphanizomenon gracile. Harmful Algae 37:28-37.

Christiansen G, Kurmayer R, Liu Q, Börner T, 2006. Transposons inactivate biosynthesis of the nonribosomal peptide microcystin in naturally occurring Planktothrix spp. Appl. Environ. Microbiol. 72:117-123.

Cirés S, Wörmer L, Ballot A, Agha R, Wiedner C, Velazquez D, Casero MC, Quesada A, 2014. Phylogeography of cylindrospermopsin and paralytic shellfish toxin-producing Nostocales cyanobacteria from mediterranean europe (Spain). Appl. Environ. Microbiol. 80:1359-1370.

Cirés S, Ballot A, 2016. A review of the phylogeny, ecology and toxin production of bloom-forming Aphanizomenon spp. and related species within the Nostocales (cyanobacteria). Harmful Algae 54:21-43.

D'Agostino PM, Moffitt MC, Neilan BA, 2014. Current knowledge of paralytic shellfish toxin biosynthesis, molecular detection and evolution, p. 251-280. In: Rossini, G.P. (ed.), Toxins and biologically active compounds from microalgae.1. CRC Press.

Dias E, Pereira P, Franca S, 2002. Production of paralytic shellfish toxins by Aphanizomenon sp. LMECYA 31 (Cyanobacteria). J. Phycol. 38:705-712.

Diener M, Erler K, Christian B, Luckas B, 2007. Application of a new zwitterionic hydrophilic interaction chromatography column for determination of paralytic shellfish poisoning toxins. J. Sep. Sci. 30:1821-1826.

Gkelis S, Zaoutsos N, 2014. Cyanotoxin occurrence and potentially toxin producing cyanobacteria in freshwaters of Greece: A multi-disciplinary approach. Toxicon 78:1-9. 
Hautala H, Lamminmäki U, Spoof L, Nybom S, Meriluoto J, Vehniäinen M, 2013. Quantitative PCR detection and improved sample preparation of microcystin-producing $\mathrm{An}$ abaena, Microcystis and Planktothrix. Ecotoxicol. Environ. Saf. 87:49-56.

Jančula D, Straková L, Sadílek J, Maršálek B, Babica P, 2014. Survey of cyanobacterial toxins in Czech water reservoirs the first observation of neurotoxic saxitoxins. Environ. Sci. Pollut. R. 21:8006-8015.

Kaas H, Henriksen P, 2000. Saxitoxins (PSP toxins) in Danish lakes. Water Res. 34:2089-2097.

Kao CY, 1986. Structure-activity relations of tetrodotoxin, saxitoxin, and analogues Ann. N. Y. Acad. Sci. 479:52-67.

Kellmann R, Mihali TK, Jeon YJ, Pickford R, Pomati F, Neilan BA, 2008. Biosynthetic intermediate analysis and functional homology reveal a saxitoxin gene cluster in cyanobacteria. Appl. Environ. Microbiol. 74:4044-4053.

Kobos J, Błaszczyk A, Hohlfeld N, Toruńska-Sitarz A, Krakowiak A, Hebel A, Sutryk K, Grabowska M, Toporowska M, Kokociński M, Messyasz B, Rybak A, Napiórkowska-Krzebietke A, Nawrocka L, Pełechata A, Budzyńska A, Zagajewski P, Mazur-Marzec H, 2013. Cyanobacteria and cyanotoxins in Polish freshwater bodies. Oceanol. Hydrobiol. Stud. 42:358-378.

Kokociński M, Soininen J, 2012. Environmental factors related to the occurrence of Cylindrospermopsis raciborskii (Nostocales, Cyanophyta) at the north-eastern limit of its geographical range. Eur. J. Phycol. 47:12-21.

Kokociński M, Mankiewicz-Boczek J, Jurczak T, Spoof L, Meriluoto J, Rejmonczyk E, Hautala H, Vehniäinen M, Pawełczyk J, Soininen J, 2013. Aphanizomenon gracile (Nostocales), a cylindrospermopsin-producing cyanobacterium in Polish lakes. Environ. Sci. Pollut. Res. 20:52435264.

Lagos N, Onodera H, Zagatto PA, Andrinolo D, Azevedo SM, Oshima Y, 1999. The first evidence of paralytic shellfish toxins in the fresh water cyanobacterium Cylindrospermopsis raciborskii, isolated from Brazil. Toxicon 37:1359-1373.

Ledreux A, Thomazeau S, Catherine A, Duval C, Yéprémian C, Marie A, Bernard C, 2010. Evidence for saxitoxins production by the cyanobacterium Aphanizomenon gracile in a French recreational water body. Harmful Algae 10:88-97.

Li R, Carmichael WW, Pereira P, 2003. Morphological and 16S rRNA gene evidence for reclassification of the paralytic shellfish toxin producing Aphanizomenon flos-aquae LMECYA 31 as Aphanizomenon issatschenkoi (Cyanophyceae). J. Phycol. 39:814-818.

Llewellyn LE, 2006. Saxitoxin, a toxic marine natural product that targets a multitude of receptors. Nat. Prod. Rep. 23:200222.

Mankiewicz-Boczek J, Izydorczyk K, Romanowska-Duda Z, Jurczak T, Stefaniak K, Kokociński M, 2006. Detection and monitoring toxigenicity of cyanobacteria by application of molecular methods. Environ. Toxicol. 21:380-387.

Mihali TK, Kellmann R, Neilan BA, 2009. Characterisation of the paralytic shellfish toxin biosynthesis gene clusters in $\mathrm{An}$ abaena circinalis AWQC131C and Aphanizomenon sp. NH5. BMC Biochem. 10:8.

Murray SA, Mihali TK, Neilan BA, 2011. Extraordinary conservation, gene loss, and positive selection in the evolution of an ancient neurotoxin. Mol. Biol. Evol. 28:1173-1182. Noguchi T, Shinohara A, Nishizawa A, Asayama M, Nakano T, Hasegawa M, Harada K, Nishizawa T, Shirai M, 2009. Genetic analysis of the microcystin biosynthesis gene cluster in Microcystis strains from four bodies of eutrophic water in Japan. J. Gen. Appl. Microbiol. 55:111-123.

Nurmi J, Wikman T, Karp M, Lövgren T, 2002. High-performance real-time quantitative RT-PCR using lanthanide probes and a dual-temperature hybridization assay. Anal. Chem. 74:3525-3532.

Ongley SE, Pengelly JJL, Neilan BA, 2016. Elevated $\mathrm{Na}^{+}$and $\mathrm{pH}$ influence the production and transport of saxitoxin in the cyanobacteria Anabaena circinalis AWQC131C and Cylindrospermopsis raciborskii T3. Environ. Microbiol. 18: 427-438.

Ostermaier V, Kurmayer R, 2009. Distribution and abundance of nontoxic mutants of cyanobacteria in lakes of the Alps. Microb. Ecol. 58:323-333.

Pereira P, Onodera H, Andrinolo D, Franca S, Araujo F, Lagos N, Oshima Y, 2000. Paralytic shellfish toxins in the freshwater cyanobacterium Aphanizomenon flos-aquae, isolated from Montargil reservoir, Portugal. Toxicon 38:1689-1702.

Pereira P, Li R, Carmichael W, Dias E, Franca S, 2004. Taxonomy and production of paralytic shellfish toxins by the freshwater cyanobacterium Aphanizomenon gracile LMECYA40. Eur. J. Phycol. 39:361-368.

Pomati F, Rossetti C, Manarolla G, Burns BP, Neilan BA, 2004. Interactions between intracellular $\mathrm{Na}+$ levels and saxitoxin production in Cylindrospermopsis raciborskii T3. Microbiology 150:455-461.

R Core Team, 2015. R: A Language and Environment for Statistical Computing, Http://www.R-Project.Org. R Foundation for Statistical Computing, Vienna, Austria.

Rajaniemi P, Komárek J, Willame R, Hrouzek P, Kaštovská K, Hoffmann L, Sivonen K, 2005. Taxonomic consequences from the combined molecular and phenotype evaluation of selected Anabaena and Aphanizomenon strains. Algological Studies 117:371-391.

Rapala J, Robertson A, Negri AP, Berg KA, Tuomi P, Lyra C, Erkomaa K, Lahti K, Hoppu K, Lepistö L, 2005. First report of saxitoxin in Finnish lakes and possible associated effects on human health. Environ. Toxicol. 20:331-340.

Savela H, Spoof L, Perälä N, Preede M, Lamminmäki U, Nybom S, Häggqvist K, Meriluoto J, Vehniäinen M, 2015. Detection of cyanobacterial sxt genes and paralytic shellfish toxins in freshwater lakes and brackish waters on Åland Islands, Finland. Harmful Algae 46:1-10.

Savela H, Vehniäinen M, Spoof L, Nybom S, Meriluoto J, Lamminmäki U, 2014. Rapid quantification of $m c y B$ copy numbers on dry chemistry PCR chips and predictability of microcystin concentrations in freshwater environments. Harmful Algae 39:280-286.

Smith FM, Wood SA, van Ginkel R, Broady PA, Gaw S, 2011. First report of saxitoxin production by a species of the freshwater benthic cyanobacterium, Scytonema Agardh. Toxicon 57:566-573.

Stucken K, Murillo AA, Soto-Liebe K, Fuentes-Valdes JJ, Mendez MA, Vasquez M, 2009. Toxicity phenotype does not correlate with phylogeny of Cylindrospermopsis raciborskii strains. Syst. Appl. Microbiol. 32:37-48. 
Su Z, Sheets M, Ishida H, Li F, Barry WH, 2004. Saxitoxin blocks L-type $\mathrm{I}_{\mathrm{Ca}}$. J. Pharmacol. Exp. Ther. 308:324-329.

Wacklin P, Hoffmann L, Komarek J, 2009. Nomenclatural validation of the genetically revised cyanobacterial genus Dolichospermum (Ralfs ex Bornet et Flahault) comb. nova. Fottea 9:59-64.

Wang J, Salata JJ, Bennett PB, 2003. Saxitoxin is a gating modifier of HERG K+ channels. J. Gen. Physiol. 121:583-598.

Wiese M, D'Agostino PM, Mihali TK, Moffitt MC, Neilan BA, 2010. Neurotoxic alkaloids: saxitoxin and its analogs Mar. Drugs 8:2185-2211.

Wittwer CT, Herrmann MG, Moss AA, Rasmussen RP, 1997. Continuous fluorescence monitoring of rapid cycle DNA amplification. BioTechniques 22:130-1, 134-8.

Wörmer L, Cirés S, Agha R, Verdugo M, de Hoyos C, Quesada
A, 2011. First detection of cyanobacterial PSP (paralytic shellfish poisoning) toxins in Spanish freshwaters. Toxicon 57:918-921.

Yunes JS, De La Rocha S, Giroldo D, Silveira SBd, Comin R, Bicho MdS, Melcher SS, Sant'anna CL, Vieira AAH, 2009. Release of carbohydrates and proteins by a subtropical strain of Raphidiopsis brookii (Cyanobacteria) able to produce saxitoxin at three nitrate concentration. J. Phycol. 45:585-591.

Zapomělová E, Skácelová O, Pumann P, Kopp R, Janeček E, 2012. Biogeographically interesting planktonic Nostocales (Cyanobacteria) in the Czech Republic and their polyphasic evaluation resulting in taxonomic revisions of Anabaena bergii Ostenfeld 1908 (Chrysosporum gen. nov.) and $A$. tenericaulis Nygaard 1949 (Dolichospermum tenericaule comb. nova). Hydrobiologia 698:353-365. 